\title{
SECULAR TRENDS AND LATITUDE GRADIENTS IN SEX RATIOS AT BIRTH IN CZECHOSLOVAKIA AND THE POST-CZECHOSLOVAKIAN STATES
}

\begin{abstract}
Victor Grech
Department of Paediatrics, Mater Dei Hospital, Malta

Summary: Latitude gradients and secular trends in Europe and North America have been found in the male-female ratio at birth (M/F: male births divided by total births) which is expected to be 0.515 . Annual national data for Czechoslovakia and the post-Czechoslovakian (Czech Republic and Slovakia) countries for male and female live births were obtained from the World Health Organisation and analysed with contingency tables. This study analysed 13,123,538 live births. An overall decreasing trend in $\mathrm{M} / \mathrm{F}$ was found $(\mathrm{p}<00001)$. No latitude gradient was noted. There was an overall deficit of 15,232 male births based on an $\mathrm{M} / \mathrm{F}$ of $0.515 . \mathrm{M} / \mathrm{F}$ is declining in this region, despite well developing economies that have resisted the worldwide slowdown. An interplay of several poorly understood factors is likely.
\end{abstract}

Key words: Czeckoslovakia; Sex Ratio; Birth Rate/*trends; Infant; Newborn

\section{What is already known on this subject?}

- Latitude gradients have been found in the male-female ratio at birth (M/F: male births divided by total births) which is expected to be 0.515 .

$-\mathrm{M} / \mathrm{F}$ is declining in North America and the Europe.

- Moreover it had been shown that there is a higher incidence of male births in southern Europe than in the north, with the opposite found in North America.

\section{What this study adds?}

- Czechoslovakia and the post-Czechoslovakian states display an overall decreasing trend in $\mathrm{M} / \mathrm{F}$, like Europe and North America. No latitude gradient is noted.

Gender is determined at conception in mammals, and male births occur slightly in excess (James WH 1987). The male to female ratio of live births is expressed as the ratio of male live births divided by total live births $(\mathrm{M} / \mathrm{F})$, and for humans, this is expected, overall, to be 0.515 (James WH 1987). However, while this figure is accepted for Caucasian races, for black populations, $\mathrm{M} / \mathrm{F}$ is around $0.505-0.510$ (Chahnazarian 1988).

The reason for this discrepancy is uncertain but the number of factors that have been implicated in influencing $\mathrm{M} / \mathrm{F}$ is legion (Chahnazarian 1988; James WH 2008). These include factors that influence $\mathrm{M} / \mathrm{F}$, such as physiological characteristics both of paternal sperm and the maternal reproductive tract, and those which affect fetal survival such as viability and immunological/transplacental interactions materno-fetal interactions.

In addition, $\mathrm{M} / \mathrm{F}$ varies in geographical space, exhibiting a latitude gradient that varies by continent. More males are born towards the south of Europe, while more males are born in northern latitudes in the North American continent (Grech V et al 2000; Grech V et al 2002).

Moreover, several studies have also been shown that $\mathrm{M} / \mathrm{F}$ varies in temporal fashion, mostly declining in the above two continents (Grech V et al 2003).

Czechoslovakia was a sovereign central European country which existed from 1918 to 1992, when it peacefully split into the Czech Republic and Slovakia.

This study identifies secular trends in M/F in Czechoslovakia and the post-Czechoslovakian states from a World Health Organization (WHO) dataset. Secular trends and trends by geographical latitude are also analysed. The null hypothesis is that there were no significant geographical or secular differences in $\mathrm{M} / \mathrm{F}$.

Annual male and female live births were obtained directly from WHO. Data was available for the periods 1985-2009 for the Czech Republic and Slovakia. For 1950-1984, data was only available for Czechoslovakia.

Excel was used for data entry, overall analysis and charting. The quadratic equations of Fleiss were used for exact calculation of $95 \%$ confidence intervals for ratios (Fleiss JL 1981). Chi tests and chi tests for trends for annual male and female births were used throughout. A p value $\leq 0.05$ was taken to represent a statistically significant result.

There were 13,123,538 live births available for analysis $($ males $=6,743,390$, females $=6,380,148, \mathrm{M} / \mathrm{F} 0.51384$, CL: 0.51357-0.51411).

Five year total live births and sex ratios at births, in 5 year intervals, are shown in table 1 . There have been no significant increases or decreases in $\mathrm{M} / \mathrm{F}$ over period 1985-2009 for the Czech Republic or for Slovakia or for 
Tab. 1: 5 year total live births and sex ratios at births, in 5 year intervals

\begin{tabular}{|c|c|c|c|c|c|c|c|}
\hline & \multicolumn{7}{|c|}{ Former Czechoslovakia } \\
\hline & $1950-54$ & $1955-59$ & $1960-64$ & $1965-69$ & $1970-74$ & $1975-79$ & $1980-84$ \\
\hline M & 719872 & 634457 & 581297 & 569006 & 658599 & 722432 & 604705 \\
\hline $\mathrm{F}$ & 673773 & 597445 & 549124 & 538030 & 624240 & 686927 & 573548 \\
\hline Total & 1393645 & 1231902 & 1130421 & 1107036 & 1282839 & 1409359 & 1178253 \\
\hline UCI & 0.51737 & 0.51591 & 0.51515 & 0.51492 & 0.51426 & 0.51342 & 0.51412 \\
\hline $\mathrm{M} / \mathrm{F}$ & 0.51654 & 0.51502 & 0.51423 & 0.51399 & 0.51339 & 0.51260 & 0.51322 \\
\hline \multirow[t]{3}{*}{ LCI } & 0.51571 & 0.51414 & 0.51331 & 0.51306 & 0.51253 & 0.51177 & 0.51232 \\
\hline & \multicolumn{5}{|c|}{ Czech Republic and Slovakia } & & \\
\hline & $1985-89$ & 1990-94 & 1995-99 & $2000-04$ & 2005-09 & & \\
\hline M & 556245 & 504385 & 386025 & 374652 & 431715 & & \\
\hline $\mathrm{F}$ & 529600 & 477666 & 365887 & 353696 & 410212 & & \\
\hline Total & 1085845 & 982051 & 751912 & 728348 & 841927 & & \\
\hline UCI & 0.51321 & 0.51459 & 0.51452 & 0.51553 & 0.51384 & & \\
\hline $\mathrm{M} / \mathrm{F}$ & 0.51227 & 0.51360 & 0.51339 & 0.51439 & 0.51277 & & \\
\hline LCI & 0.51133 & 0.51261 & 0.51226 & 0.51324 & 0.51170 & & \\
\hline
\end{tabular}

\begin{tabular}{|l|l|l|l|l|l|}
\hline \multirow{2}{*}{} & \multicolumn{5}{|c|}{ Czech Republic $-48^{\circ}$ to $51^{\circ} \mathrm{N}$} \\
\cline { 2 - 6 } & \multicolumn{1}{|c|}{$1985-89$} & $1990-94$ & \multicolumn{1}{|c|}{$1995-99$} & \multicolumn{1}{|c|}{$2000-04$} & \multicolumn{1}{|c|}{$2005-09$} \\
\hline M & 339007 & 313134 & 234820 & 239785 & 287234 \\
\hline Total & 322181 & 296093 & 222386 & 225975 & 273358 \\
\hline UCI & 661188 & 609227 & 457206 & 465760 & 560592 \\
\hline M/F & 0.51393 & 0.51524 & 0.51505 & 0.51626 & 0.51369 \\
\hline LCI & 0.51272 & 0.51399 & 0.51360 & 0.51483 & 0.51238 \\
\hline \multirow{2}{*}{ F } & 0.51152 & 0.51273 & 0.51215 & 0.51339 & 0.51107 \\
\hline & $1985-89$ & $1990-94$ & $1995-99$ & $2000-04$ & $2005-09$ \\
\hline M & 217238 & 191251 & 151205 & 134867 & 144481 \\
\hline F & 207419 & 181573 & 143501 & 127721 & 136854 \\
\hline Total & 424657 & 372824 & 294706 & 262588 & 281335 \\
\hline UCI & 0.51307 & 0.51458 & 0.51488 & 0.51552 & 0.51540 \\
\hline M/F & 0.51156 & 0.51298 & 0.51307 & 0.51361 & 0.51356 \\
\hline LCI & 0.51006 & 0.51137 & 0.51126 & 0.51169 & 0.51171 \\
\hline
\end{tabular}


the amalgamation of the two. However, there was a significant declining trend in $\mathrm{M} / \mathrm{F}$ for Czechoslovakia and its continuation as the amalgamated total of the two abovementioned states, for the period 1950-2009 (chi for trend 29.8, d.f. 50, p < 0.0001).

There were no significant differences in $\mathrm{M} / \mathrm{F}$ for the two periods 1985-93 and 1994-2009 within the Czech Republic and within Slovakia (table 2).

Tab. 2: Births for the Czech Republic and for Slovakia pre- and post-split for available years

\begin{tabular}{|c|c|c|}
\hline & Czech Republic & Slovakia \\
\hline \multicolumn{3}{|c|}{ 1985-1993 } \\
\hline M & 597,437 & 816,543 \\
\hline $\mathrm{F}$ & 566,399 & 773,594 \\
\hline $\mathrm{T}$ & $1,163,836$ & $1,590,137$ \\
\hline UCI & 0.51424 & 0.51428 \\
\hline $\mathrm{M} / \mathrm{F}$ & 0.51333 & 0.51350 \\
\hline LCI & 0.51243 & 0.51273 \\
\hline \multicolumn{3}{|c|}{ 1994-2009 } \\
\hline M & 816,543 & 464,428 \\
\hline $\mathrm{F}$ & 773,594 & 440,571 \\
\hline $\mathrm{T}$ & $1,590,137$ & 904,999 \\
\hline UCI & 0.51428 & 0.51421 \\
\hline $\mathrm{M} / \mathrm{F}$ & 0.51350 & 0.51318 \\
\hline LCI & 0.51273 & 0.51215 \\
\hline
\end{tabular}

The Czech Republic and Slovakia differ only very slightly in latitude (headings right side of table 1). Analysis by latitude, that is, comparing the Czech Republic and Slovakia, showed no significant differences in $\mathrm{M} / \mathrm{F}$, for the two periods 1985-93 and 1994-2009, and for the aggregate values of both regions.

There was an overall deficit of 15,232 male births based on an $\mathrm{M} / \mathrm{F}$ of 0.515 .

No latitude gradient is apparent in this study, and this may be due to the small latitude difference between these two regions.

$\mathrm{M} / \mathrm{F}$ has been shown to be declining in Europe and in North America after 1950 (Grech V et al 2003) and these results are in agreement. However, studies that extend before 1950 demonstrate an increase in M/F for all Nordic countries before this time. For Norway and Denmark, $\mathrm{M} / \mathrm{F}$ increased (1801-1950), and an even more significant increase was found in Finland (1751-1950) and Iceland (1838-1950) (Fellman et al 2002).

Several attempts have been made in order to identify potential factors that may influence $\mathrm{M} / \mathrm{F}$. Interestingly, no reliable associations between secondary sex ratios and stillbirth rates have been made (Fellman \& Eriksson 2011).

An extensive review concluded that maternal age probably has little effect on $\mathrm{M} / \mathrm{F}$ while younger fathers may increase $\mathrm{M} / \mathrm{F}$, as may birth order. Futhermore, the study concluded that the effects of socioeconomic status remain unclear, that racial variation appears to be an independent factor and that all effects are very small. Moreover, these abovementioned factors do not completely explain observed M/F variations (Chahnazarian 1988).

Certain human malformations (Arena and Smith 1978) and parental disorders (James 1987) have also been linked to skewed M/F. Additionally, large families, ancestral longevity, excessive parental intake of coffee, high frequency of coitus and pregnancies that occur outside of wedlock have also been shown to skew M/F (Teitelbaum 1972).

James has proposed that $\mathrm{M} / \mathrm{F}$ varies, peaking and ebbing over a thirty cycle, a homeostatic mechanism that negatively correlates $\mathrm{M} / \mathrm{F}$ with the adult sex ratio at the time of conception (James WH 1995). However, no such peaks are evident in this study.

$\mathrm{M} / \mathrm{F}$ has been shown to decline in response to adverse environmental or other factors such as stressful events, and it has been proposed that $\mathrm{M} / \mathrm{F}$ is depressed by excess prenatal fetal losses. These include warfare (Zorn B et al 2002), earthquakes (Fukuda $M$ et al 1998), and other environmental disasters (Lyster WR 1974). Such events have been shown to reduce $\mathrm{M} / \mathrm{F}$ by encouraging stressed females to spontaneously abort male fetuses in excess of female fetuses (Byrne J and Warburton D 1987). Contracting economies have also been shown to reduce $\mathrm{M} / \mathrm{F}$ (Catalano RA 2003), but the data supporting this theory is not strong, probably because large datasets are required to demonstrate small changes in M/F. Indeed, some studies, such as those involving Afro-Americans in the United States, have failed to demonstrate a socioeconomic effect M/F (Visaria 1967). Furthermore, recent attempts to correlate $\mathrm{M} / \mathrm{F}$ with stillbirth rates in Nordic countries have not been successful (Fellman \& Eriksson 2011). A genetic predisposition that skews $\mathrm{M} / \mathrm{F}$ has also been posited, but no genes have been linked to such a purported trait (Fellman et al 1999).

The overall decline in $\mathrm{M} / \mathrm{F}$ in industrialised countries has been linked to environmental toxin exposure, such as pesticides, oestrogens and oestrogen-like compounds (Visaria 1967; Chahnazarian 1990), but it has been noted that the decline witnessed precedes the widespread introduction of the abovementioned compounds in the environment (Fellman \& Eriksson 2011).

In this study, the economies of both regions rose constantly up to 2010 , with an ever-rising gross national product despite a general European, and indeed worldwide, economic slowdown (Central Intelligence Agency 2010), and no major disasters befell this region. Several factors may be affecting $\mathrm{M} / \mathrm{F}$, producing the decline in developing countries. 


\section{Acknowledgements}

Mie Inoue and Gauden Galea from the World Health Organisation.

\section{References}

1. Arena JFP, Smith DW (1978). Sex liability to single structural defects. Am J Dis Child 132: 970-972.

2. Byrne J, Warburton D (1987). Male excess among anatomically normal fetuses in spontaneous abortions. American Journal of Medical Genetics 26, 605-11.

3. Catalano RA (2003). Sex ratios in the two Germanies: a test of the economic stress hypothesis. Human Reproduction 18, 1972-5.

4. Central Intelligence Agency (1997-2010). CIA World Factbook. Washington, DC: Central Intelligence Agency.

5. Chahnazarian A (1988). Determinants of the sex ratio at birth: Review of recent literature. Soc Biol 35: 214-235.

6. Fellman J, Eriksson AW (2011). Temporal trends in the secondary sex ratio in Nordic countries. Biodemography and Social Biology 57, 143-54.

7. Fellman J, Eriksson AW, Forsius H (2002). Sex ratio and proportion of affected sons in sibships with X-chromosomal recessive traits: maximum likelihood estimation in truncated multinomial distributions. Human Heredity $53: 173-80$

8. Fleiss JL (1981). Statistical methods for rates and proportions. New York: John Wiley and Sons, 1981: 14-15 (2nd edition)
9. Fukuda M, Fukuda K, Shimizu T, Møller H (1998). Decline in sex ratio at birth after Kobe earthquake. Human Reproduction 13, 2321-2.

10. Grech V, Vassallo-Agius P, Savona-Ventura C (2000). Declining male births with increasing geographical latitude in Europe. Journal of Epidemiology and Community Health 54, 244-246.

11. Grech V, Vassallo-Agius P, Savona-Ventura C (2002). Unexplained differences in the sex ratio at birth in Europe and North America. British Medical Journal 324, $1010-1011$.

12. Grech V, Vassallo-Agius P, Savona-Ventura C (2003). Secular trends in sex ratios at birth in North America and Europe over the second half of the 20th century. Journal of Epidemiology and Community Health 57, 612-5.

13. James WH (1987). The human sex ratio. Part 1: A review of the literature. Human Biology 59, 721-52.

14. James WH (1995). What stabilizes the sex ratio? Annals of Human Genetics 59 (Pt 2), 243-249.

15. James WH (2008). Evidence that mammalian sex ratios at birth are partially controlled by parental hormone levels around the time of conception. Journal of Endocrinology 198, 3-15.

16. Lyster WR (1974). Altered sex ratio after the London smog of 1952 and the Brisbane flood of 1965. Journal of Obstetrics and Gynaecology of the British Commonwealth 81, 626-31.

17. Teitelbaum, MS (1972). Factors associated with the sex ratio in human populations. In The structure of human populations, ed. G. A. Harrison and A. J. Boye, 90-109. Oxford: Clarendon Press.

18. Visaria PM (1967). Sex ratio at birth in territories with a relatively complete registration. Eugen Q 14: 132-142.

19. Zorn B, Sucur V, Stare J, Meden-Vrtovec H (2002). Decline in sex ratio at birth after 10-day war in Slovenia: brief communication. Human Reproduction. 17, 3173-7.

Received: $23 / 05 / 2012$

Accepted in revised form: 09/09/2012

\section{Corresponding author:}

Prof. Victor Grech, Department of Paediatrics, Mater Dei Hospital, Malta; e-mail: victor.e.grech@gov.mt 